\title{
The pitfalls and promises of an academic approach to solving real world problems in local government
}

\author{
Jennifer Scott ${ }^{\mathrm{a}}$, Jennie Cramp ${ }^{\mathrm{b}}$, Sophia Findlay ${ }^{\mathrm{c}}$ and $^{\top}$ Jay Jonasson $^{\mathrm{d}}$ \\ a Sustainability Program Leader, Ku-ring-gai Council, jscott@kmc.nsw.gov.au \\ ${ }^{\mathrm{b}}$ Technical Officer, Bushfires, Ku-ring-gai Council \\ ${ }^{\mathrm{c}}$ Water and Catchments Program Leader, Ku-ring-gai Council \\ ${ }^{\mathrm{d}}$ Environmental Engineer, Ku-ring-gai Council
}

\begin{abstract}
Traditionally many local government entities have been entrenched in a system of no change. Change has been regarded as a threat to available resources, existing projects, and to top-down risk adverse management's control of priorities. Local governments are not usually regarded as research hubs. However, the highly localised and complex nature of many environmental management issues, in particular, often means research is essential to ensure effective and efficient management. Dealing with issues of a high magnitude of complexity is thought to be beyond the scope of Councils and better left to state and federal agencies. In recent years this perception is proving increasingly false. Despite the lack of recognition, difficult internal management priorities, and a community unaware of the benefits, several local councils have managed to create a substantial research profile designed to address important knowledge gaps.

Ku-ring-gai Council has benefited greatly from the development of a research agenda. Management has recognised the value of fostering innovation, the dangers of clinging onto the old mantra 'if it ain't broke, don't fix it', and the positive effects a culture of problem solving can have for staff and the overall wellbeing of the community. Although research into pressing environmental management issues including water, bushfire and climate change has not been without substantial challenges, the benefits of this approach are clear - ensuring that already limited resources are being spent where they will have the greatest effect. Through continued research, monitoring and review, this provides a basis on which to make sound managerial decisions.
\end{abstract}

\section{Introduction}

Local government has always been expected to function as a 'jack of all trades', and it may once have been argued that it was a 'master of none'. In years past local government functioned to meet the much simpler needs of their local constituents (Dale 2008). The domain of local government was confined to the function of 'roads, rates and rubbish' 
service delivery. This paper will argue that today this premise does not, and should not hold true. Local government is the most exposed level of government to public scrutiny and the closest level of government to the community. As a result it has transitioned from a traditional form of 'government' of yesteryear to an administration system more defined by community engagement and the characteristics of 'governance' (Pillora \& McKinlay 2011).

\section{The transition to governance}

According to the Organisation for Economic Co-operation and Development (OECD) (cited in Pillora \& McKinlay 2011), good governance has defining characteristics including being participatory, consensus oriented, accountable, transparent, responsive, effective, efficient, equitable and law abiding. Government on the other hand is characterised by decision making in narrowly focused on prescriptive administrative and legislative frameworks (Hambleton cited in Pillora \& McKinlay 2011).

The transition from the traditional model of government to one that integrates the practice of governance into government has emerged in an ad hoc fashion within Australian local government over the past few decades. Dale's research into the role of contemporary local government in Victoria finds consensus regarding the role of local government (Dale 2011). Respondents in Dale’s research regarded local government's role to be services, democratic representation, infrastructure, community building, advocacy, governance and planning for the community. This description, if taken as an order of priority, demonstrates that service oriented roles of local government still take precedence- nevertheless elements of governance are also present. Governance, while integral to the truly local democratic process, appears to take a lesser profile. This suggests that the transition between government and governance is fluid and may always be so.

State of the environment (SoE) reporting in New South Wales over the past decade demonstrates the difficulty in bridging the nexus between government and governance. Kelly (2011) discusses the increasing complexity and demands for public performance reporting in local government in the 20 years between 1991 and 2011. SoE reports were semi-prescriptive documents founded on a bottom-up approach. While local government in NSW was legally obligated to produce these reports, Kelly (2011) found the documents served no internal function for most councils, with senior managers ignorant of their content. Kelly notes that SoEs have had to be re-designed to be more applicable and flexible. 
Council management plans in NSW have made the transition from only a prescriptive annual report to include a community strategic plan (CSP), which is described as a plan for the community rather than just council. According to Kelly (2011), the CSP seeks to integrate civic leadership with social, environmental and economic issues, or in other words a quadruple bottom line approach. Such an approach sees state and local governments and communities coming together in a straightforward process that feeds directly through to councils' operational plans for implementation. Whether this revitalised SoE process is effective in creating grounded outcomes remains a question. It does however provide an example of the transition local government is making in toward improved governance and better informed, more transparent and accountable decision making.

While external and internal reporting systems may function more transparently, the degree of complexity in decision making at the local level has increased in a more governance oriented system. This complexity has given rise to the need for better information to support the decision making process.

\section{The impact of development on local values}

In Australia the growth of cities has been significant. The urbanised footprint has expanded into productive farm land and nature conservation areas in almost every state and territory.

According to Crichton (2010) the Department of Foreign Affairs and Trade (DFAT) figures show Australia as one of the most urbanised and coastal-dwelling populations worldwide. In Australia, over 80 per cent of people live within 100 kilometres of the coast. Sydney's population is rapidly expanding and is predicted to reach six million within the next twenty years (Crichton 2010). In the Ku-ring-gai area, a local government area northwest of the Sydney CBD, growth occurs mainly from infill development and implementation of the Local Environmental Plan (LEP). In the years between 2000 and 2005 Ku-ring-gai's population was in a slow decline, however from 2007 to 2012 the population in Ku-ring-gai has increased by an average of $1.74 \%$ per annum (Demographic profile 2011). This trend appears set to continue with the planned intensification of the urban footprint in the municipality (DoP 2007).

Problems arise when growth impacts the values that local communities have inherited from past communities. These values are often in the form of natural assets, cultural and heritage items, and productivity and employment. These values are perceived by local communities to be intrinsic to the quality of life in the local area. The challenge for local government is the need to maintain these values while simultaneously instructed by 
higher levels of government to allow what could be argued as barely fettered development to occur. This tension requires careful analysis to avoid the often seen result of win/lose - generally the local values lose and the development imperative wins.

\section{Integrating different knowledge}

Making the shift between government and governance models of decision making in an environment where tensions on decision makers are multiplying demands a transparent and reasoned process. Such a process is underpinned by good quality research capable of incorporating both quantitative and qualitative methods. Within the quasi governance/government world, many different voices compete to be heard. From professional lobbyists to subject experts, local residents, and other layers of government and non-government associations, all these voices seek to influence decisions.

Experienced researchers understand the need to moderate the squeaky wheel with robust inquiry methods and transparent analytical techniques that lead to clearly validated outcomes. Basing decisions on accepted methods that incorporate all voices wishing to influence a decision has social, political and legal acceptance. Outcomes need to be completed through integration into council practice and community action. Collaborative learning frameworks which support knowledge integration processes rather than knowledge products have gained favour in recent times (Raymond et al. 2010). Raymond et al. (2010) claim such processes need to exhibit a cyclic nature, and be reflexive and systematic. The challenge for today's researchers say Raymond et al. (2010) is to create user-inspired and user-useful strategies. Nowhere is this more necessary than in local government.

Integrating various knowledge types into a decision making framework should assist in creating solutions that are grounded, applicable and user-oriented. Creating solutions inside the workplace rather than consultants doing the job as external observers strengthens the likelihood of creating user-oriented results. There is no single correct technique for combining scientific and local knowledge. The complexity of many of the issues confronting local government such as budget prioritisation for natural area management, stormwater controls, natural systems conservation, emergency management and climate change, for example, may need different approaches. Every approach should be underpinned by solid methods, inclusiveness and open lines of inquiry. Above all, the impact of the solution needs to be well thought through as the solution can lead to both intended and unintended consequences. Innovation is not without its risks; the rewards can be great but failures are not to be underestimated. 


\section{Innovation}

Local government is not generally regarded as an innovation hub, though this perception has recently been changing in councils' favour. It is now better understood in many councils that to make the transition into governance, there is a need to create a culture that fosters innovative responses to problems. Creativity requires a wide variety of inputs and the systemic analysis to select which alternatives should be retained to address the problem at hand (Martin n.d.) The problem needs to be viewed in the context of all stakeholders. A functioning internal research culture within an organisation fosters motivation, whereas relying on external motivators for problem solving capacity has a disengaging effect. Researchers are, by definition, innovators. Researchers are, by necessity, self-motivated and thrive on the desire to solve tangible problems.

\section{Examples of successful research outcomes in Ku-ring-gai Council}

Pelz and Munson (cited in Dale n.d., p. 4) cite four stages in innovation:

- Diagnosis - problem has a solution identified

- Design - development of the detail of the solution

- Implementation - solution embedded

- Stabilisation - innovation proves successful, it requires adjustment or it is abandoned.

These four stages more or less describe a quality research method. The following two case studies undertaken within Ku-ring-gai Council in recent years demonstrate how these four stages have been used as a research framework in action. These case studies are the product of an active research culture currently building the problem solving capacity inside Ku-ring-gai Council. The first case study deals with the problem of disaster preparedness in a changing climate, and the second deals with improved water management in the Council area.

\section{Case Study 1: Climate change adaptation to address bushfire risk and disaster management}

The risks emerging from changing weather patterns include more frequent and intense extreme weather events such as bushfire, storms, droughts and heat waves (Kuring-gai Council 2011). Ku-ring-gai Council has experienced many extreme weather events in the past. In 2007 Council began an ongoing research process to investigate and address the risks facing the community from climate change. In 2008, research and 
workshops with experts and the local community confirmed that bushfires were considered to be the single most serious threat to the area (Ku-ring-gai Council 2011).

Ku-ring-gai Council is responsible for the management of 1,100 hectares of bushland that largely intersects with densely populated residential areas. Much of this bushland is contiguous with larger natural areas to the north, south-west and east, making it one of the most bushfire-prone areas in Greater Sydney and Australia-wide (Chen 2005).

Ku-ring-gai has a history of destructive fires impacting the urban/bushland interface, with large scale and intense wildfires impacting the area on average once every 10 years (HKBFMC 2010). The physical setting, development and demographic profile contribute to the area's vulnerability to bushfire. This risk is exacerbated by increasing populations and development on the bushland interface escalating the bushfire risk to human life as people increasingly place themselves in more vulnerable locations (Cottrell et al. 2008; Erikson \& Prior 2011).

Land owners and managers - including Council - have statutory obligations to prevent the occurrence of, and to minimise the danger from the spread of bushfires (Rural Fires Act 1997). These obligations, however, need to be enacted without totally compromising the basis for which the land is managed, which is primarily to ensure the long-term conservation of the natural values while also responsibly caring for our community.

There needs to be a commitment from all land managers to undertake adequate fuel management and ensure that fire protection measures are addressed in urban planning and development through a means that also respects ecological values. However, defining what is deemed 'adequate' is complicated by the knowledge that weather patterns will alter as a response to $\mathrm{CO}_{2}$ concentrations in the atmosphere. The changes will likely result in a longer fire season, increased frequency of extreme or catastrophic fire-risk days, increased fire intensity, reduced opportunity to undertake prescribed burning, and a decreased effectiveness of hazard reduced areas to provide protection under extreme conditions (Lucas et al. 2007; Hennessy et al. 2005; McCarthy \& Tolhurst 2001 cited in Fernandes \& Bortelho 2003).

Traditional measures applied to reduce the risk of bushfire have proved inadequate in the face of large scale, catastrophic fires (VBRC 2009). With this knowledge, Council invested in research with the aim to better prepare and protect its community and natural environment to the risks from bushfires and other natural hazards which are likely to impact the Ku-ring-gai area.

Regional climate change modelling produced by the CSIRO (2007) and the Bureau of Meteorology (2013) was analysed by Macquarie University in partnership with Bond 
University and Ku-ring-gai Council. This research contributed to the development of a downscaled model for the Ku-ring-gai local government area (Taplin et al. 2010). This climate change modelling suggests that the Ku-ring-gai area may be particularly vulnerable to increased fire and storm activity as well as increased exposure to drought and extreme heat. The modelling was used to inform the development of a climate change adaptation strategy. As part of this process vulnerability and resilience factors were evaluated and the residual risks identified. An analytical model was then developed to re-evaluate the traditional cost-benefit method to develop prioritised adaptation options. The model provides decision makers with highly robust community referenced information that clearly sets out the expected performance of each adaptation measure, as well as the monetary and non-monetary costs associated with implementation.

\section{i. Climate Wise Communities program}

The adaptation strategy was completed in 2010. The key adaptations emerging from the merit analysis demonstrated sustainability and risk reduction to more than one hazard type.

The Climate Wise Communities (CWC) program developed in 2012 sought to deliver these high priority adaptations. The CWC program was the synthesis of several of the leading adaptations emerging from the adaptation analysis. Initially, three pilot workshops were conducted which focused on bushfires. These workshops tested a new participatory engagement method developed by RMIT University (Akama et al. 2012) to enable community members to identify bushfire hazards, self-assess their vulnerability, and examine the adequacy of their bushfire plans. This method guides self-assessment across the personal, property and neighbourhood dimensions. It promotes the reality of shared responsibility as central to reducing vulnerability and explores the local context through people's experience of past bushfire events. This method highlights the resilience benefits from participating in an interdependent network. It also allows the most vulnerable residents to be included in the wider neighbourhood response framework without being labelled as 'vulnerable'.

Participation was enhanced by targeting existing community networks such as schools and Bushcare groups, and through the neighbourhood's 'social facilitator' because such people often bind others to their neighbourhoods. The participatory nature of the workshops provided excellent opportunities for residents to develop and strengthen local connections, share past experiences, explore locally relevant questions, and clarify areas of concern. This interactive format proved valuable in developing shared responsibility compared with more traditional methods of presentation (Ku-ring-gai Council 2012a). 
The challenge for Ku-ring-gai Council now is to expand the RMIT method into a multihazard approach including bushfire, storms, floods and extreme heat.

While this external program was proceeding, Council also reviewed its own emergency management procedures. Emergency management can be divided into preparation, response and recovery phases. Council participates in a regional emergency management committee that focuses strongly on the response phase. Emerging trends in improved emergency management also places emphasis on preparation and recovery, and it is in these phases that local government has a key role to play. As part of Council's continuing research agenda, staff have reviewed emergency management arrangements in other areas and listened carefully to the experience of those who have recently had to deal with large scale natural disasters in their areas.

The stories emerging suggest that councils have largely been caught short when disasters occur, whether it be bushfires, cyclones, floods or earthquakes. Moreover, communities routinely turn to councils for answers as they are the tier of government closest to those directly affected by natural disasters. Ku-ring-gai has developed an improved understanding of the potential role that a Council can play in the preparation and recovery phases of disaster management, and the benefits of utilising existing community networks to develop preparation and recovery strategies.

Climate change risk assessment and adaptation planning have the characteristics of a 'wicked' problem, that is they can be difficult to define (spatially and chronologically), they often have interdependencies and are multi-causal, the risks are variable in type and magnitude according to the context, they are socially complex, responsibility sits with more than one organisation, and the solutions rely on changing behaviours (APSC 2007).

Research including Council's own climate change adaptation work points out that there are many common elements to disasters and addressing disasters through a multihazard lens is more efficient in terms of time and money (Field et al. 2012; APSC 2007; Ku-ring-gai Council 2011). For example, bushfire weather not only carries with it a heightened risk of wildfire, it also carries other primary risks including illness from extreme heat. Secondary risks including water and power disruptions, disrupted access to goods and services, burdens on the provision of temporary accommodation, and loss of income. These complexities are currently being translated from Council's adaptation policy and strategy into the local region's emergency response procedures.

Council's Strategy and Operations departments are working together to review new state based Emergency Management Plans to develop improved volunteering opportunities for the preparation and recovery phases of disasters, resource acquisition and allocation strategies, and logistics for medium to longer term recovery support for those affected in the community. 


\section{ii. Landuse planning options to reduce bushfire risk}

The climate change research also assisted in providing an evidence base behind introducing measures into Council's principal LEP that address an increasing risk of bushfires. An extensive background study was developed in 2011 which examines the context within which the risks occur, including local influences on bushfire behaviour, likely changes under climate change, vulnerability, resilience, and response capability and capacity (Ku-ring-gai Council 2012b). The background study outlined 25 recommendations that have expanded on the measures described in New South Wales' key bushfire landuse planning document, Planning for Bushfire Protection (2006). The study recognises that existing approaches to bushfire management, while they should continue, are alone not enough to protect lives and properties. Indeed, the physical environment, developments, and changing demographics all act to heighten the risk. For example, most of Ku-ring-gai's developments close to the bushland interface were constructed prior to the introduction of construction standards and mandatory bushfire protection measures, and are also primarily located on ridge tops with inadequate road networks to enable safe evacuation (Cova 2005 cited in Ku-ring-gai Council 2012b). Kuring-gai also has a high proportion of aged care facilities, schools and hospitals located within these high evacuation risk areas.

Key recommendations include:

- Restricting intensification of land use in high evacuation risk areas through introducing minimum lot sizes

- Applying environmental zoning where environmental hazards require careful consideration, planning, siting and design.

- Applying a minimum lot depth to sites that contain land within 55 metres of bushfire prone land that is identified as extreme risk (HKBFMC 2010).

\section{Case study 2 - water management}

Ku-ring-gai Council has diverse riparian ecosystems including some of the most intact systems with the best water quality in the Northern Sydney area (NSROC 201011). Cost effective and meaningful waterway management is a key issue for Ku-ring-gai Council's natural areas and sustainability team. Due to its urban bushland setting, Kuring-gai's natural streams are threatened by development creating increased runoff. This in turn alters the physical, biological and chemical properties of the water, contributes to accelerated erosion, increases sediment deposits, exacerbates local flooding, creates a proliferation of weeds, and results in a loss of habitat and biodiversity (Ku-ring-gai 
Council 2004). To address water management in this urban setting, Council is actively involved in a variety of water research projects with a number of different universities.

In the largest of these projects Council is an industry partner in the Cooperative Research Centres (CRC) for Water Sensitive Cities. This is a project of national and international research significance for the future urban water industry both in Australia and overseas. Ku-ring-gai Council decided to join the CRC as it provided an opportunity to influence, in a small way, the future of water sensitive urban design from a local government perspective. However, as a small partner in a large project, it can be difficult to get your voice heard, and by joining a consortium of other councils from the Sydney region the councils' collective influence had increased.

The benefits to Council of participating in this research have included the possibility to undertake sampling of stormwater treatment systems that would have otherwise fallen outside Council's financial capacity. As a partner in the CRC, Ku-ring-gai is able to partner with Universities in Melbourne and Brisbane to share the cost of sourcing and installing the sampling equipment. The samples collected have been processed at a fraction of the normal cost of a commercial laboratory. In addition, studies conducted as part of the CRC research are looking for less commonly investigated pollutants and contaminants for which testing is not normally offered by commercial laboratories. This includes an investigation into alternative meaningful indicators to be used for regular monitoring programs. This gives Ku-ring-gai's staff additional understanding of water management issues that is not normally available outside of specialised research institutions.

Participation in the CRC for Water Sensitive Cities has provided Ku-ring-gai with information that has helped guide design standards and, in turn, provided greater environmental benefits to Council's stormwater treatment program. The involvement in this large project has also provided good opportunities for networking and sharing ideas with other Councils and a number of research institutions across Australia.

Council also frequently partners with local universities on smaller, locally significant projects. Maintaining active research partnerships with local universities provides $\mathrm{Ku}-$ ring-gai with access to experts in relevant fields, as well as students that can undertake smaller research projects for Council as part of their curriculum. Each year, final year and honours students are available to apply the skills developed through their studies to address an environmental management research question that is specific to Ku-ring-gai. These projects have a number of benefits for the Council as well as the students. Often, relying state, national or international research and management guidelines does not address locally unique issues. Having local university researchers and students investigate issues, for example in providing estimates of the amount of potable water that 
contributes to base flow, can help establish more accurate local environmental health guidelines and approaches to management.

Not only does partnering with research institutions help address locally unique management issues, it can also be used to legitimate policy. For example, Council partnered with researchers and honours students from the University of Western Sydney in investigating how concrete drainage infrastructure impacts on water quality. The results influenced Council's policy on using concrete in sensitive environments and has provided a more holistic understanding of what is required to ensure improved environmental performance. This research has also been used in a NSW Land and Environment Court conciliation conference as justification to minimise the amount of concreted hard surfaces constructed near sensitive aquatic ecosystems when other more environmentally sensitive options exist. In addition, other research undertaken by Council staff on water management, riparian zones and waterway health has also been used to provide background evidence and establish the council officers' expertise when required to act as an expert witness.

\section{Lessons learned from case studies}

In the past, staff were not encouraged to look much beyond legal and policy compliance. Shining a light into dark corners was thought to simply be the cause of angst and had the potential to create unwelcome imposts on departmental budgets.

According to the Commonwealth Auditor-General in 2009 the public sector needs to embrace innovation, and therefore research, if it is to deal with future challenges and take full advantage of emergent opportunities.

The Commonwealth Auditor-General (2009, p. 14) states that the public sector can be innovative if:

It is committed to achieving a supportive culture where innovation is encouraged and lessons disseminated

- Innovation is embedded in corporate strategy and adequately resourced

- Staff have the requisite skills, training and development opportunities

- Departments and agencies encourage internally-generated innovation and actively engage with citizens, clients and stakeholders to garner external ideas and innovations

- There is a deep understanding of core business, government policy and aspirations, the broader external environment and internal and external sources of data and information 
- There are mechanisms in place to assess and respond to new and emerging issues

- Departments and agencies build organisational capabilities and agility

- Innovation is appropriately recognised and rewarded.

Table 1 utilises the key lessons cited by the Commonwealth Auditor-General to evaluate institutional learning fostered by the case studies cited in this paper.

Tab. 1. The engagement of key institutional learning criteria in the abovementioned case studies on water management and climate change.

\begin{tabular}{|c|c|c|}
\hline Learning criteria & Climate change case study & Water case study \\
\hline $\begin{array}{l}\text { Research was } \\
\text { disseminated }\end{array}$ & $\begin{array}{l}\text { Dissemination via peer reviewed } \\
\text { journals, conference presentations and } \\
\text { workshops, both domestically and } \\
\text { internationally, including by research } \\
\text { students undertaking postgraduate } \\
\text { and undergraduate projects on } \\
\text { different aspects of Council led } \\
\text { research. }\end{array}$ & $\begin{array}{l}\text { Dissemination via peer reviewed } \\
\text { journals, conference presentations and } \\
\text { participation in expert workshops. }\end{array}$ \\
\hline $\begin{array}{l}\text { Innovation was } \\
\text { resourced }\end{array}$ & $\begin{array}{l}\text { Council allocated staff time and funds } \\
\text { to collaborate with Macquarie } \\
\text { University and others. Other council } \\
\text { staff indirectly related to the project } \\
\text { were allocated time to assist with } \\
\text { expert input e.g. economists and } \\
\text { bushfire officer. }\end{array}$ & $\begin{array}{l}\text { Staff and funds committed to facilitate } \\
\text { participation in CRC research and } \\
\text { collaborate with experts on possible } \\
\text { outcomes. }\end{array}$ \\
\hline $\begin{array}{l}\text { Skills were internally } \\
\text { available }\end{array}$ & $\begin{array}{l}\text { Research skills, project management } \\
\text { skills and engagement skills sourced } \\
\text { internally. Collaborative research with } \\
\text { the tertiary sector built the collective } \\
\text { skill profile. }\end{array}$ & $\begin{array}{l}\text { High level engineering and scientific } \\
\text { skills available internally. This allowed } \\
\text { project managers to contribute to the } \\
\text { work of the CRC and helped to guide } \\
\text { research students investigating } \\
\text { smaller, local issues. }\end{array}$ \\
\hline $\begin{array}{l}\text { External knowledge } \\
\text { sought and applied }\end{array}$ & $\begin{array}{l}\text { Expert, local, strategic and political } \\
\text { knowledge utilised. External } \\
\text { knowledge supported by local } \\
\text { knowledge allowed for adaptations to } \\
\text { be highly relevant and contextualised. }\end{array}$ & $\begin{array}{l}\text { External knowledge available through } \\
\text { the CRC and within the Sydney Council } \\
\text { Consortium expanded the range of } \\
\text { options and solutions that could be } \\
\text { applied to solve problems. Partnering } \\
\text { with universities and facilitating } \\
\text { projects for research students helped } \\
\text { to identify key solutions to many local } \\
\text { issues. }\end{array}$ \\
\hline $\begin{array}{l}\text { Staff able to respond } \\
\text { to emerging issues }\end{array}$ & $\begin{array}{l}\text { Staff given the flexibility to respond to } \\
\text { not just emerging issues, but more } \\
\text { importantly emerging solutions. }\end{array}$ & $\begin{array}{l}\text { Staff able to utilise the expanded range } \\
\text { of options because of the autonomy in } \\
\text { decision making given to them. }\end{array}$ \\
\hline $\begin{array}{l}\text { Organisational } \\
\text { capacity is developing }\end{array}$ & $\begin{array}{l}\text { Staff are building a strong profile in the } \\
\text { area of adaptation planning. Skills are } \\
\text { moving beyond one department into } \\
\text { other areas of Council, e.g. disaster } \\
\text { resilience planning involving a local } \\
\text { emergency management officer } \\
\text { (known as LEMOs). Assisting other } \\
\text { Councils to implement a similar } \\
\text { strategy is assisting staff to develop a } \\
\text { deeper understanding of adaptation } \\
\text { issues. }\end{array}$ & $\begin{array}{l}\text { Continued involvement in the CRC and } \\
\text { local research projects is increasing } \\
\text { capacity for sustainable water } \\
\text { management through broadening } \\
\text { involvement of council staff and } \\
\text { integration of research outcomes into } \\
\text { council policies, plans and strategies, } \\
\text { including local planning instruments. }\end{array}$ \\
\hline $\begin{array}{l}\text { Innovation is } \\
\text { recognised and } \\
\text { rewarded }\end{array}$ & $\begin{array}{l}\text { Council has in place a system of } \\
\text { recognition for innovation that } \\
\text { includes work on policy and strategy } \\
\text { innovation. }\end{array}$ & $\begin{array}{l}\text { Council has in place a system of } \\
\text { recognition for innovation that } \\
\text { includes work on policy and strategy } \\
\text { innovation. }\end{array}$ \\
\hline
\end{tabular}


Although it doesn’t qualify as a revolution, local government culture has shifted. Today, staff search out the knowledge gaps, foster the transition from reactive to proactive budget allocation, and build knowledge based on transparent and accountable methods sourced from peer reviewed literature and research. The rigor of such investigations gives decision makers confidence and encourages them to allow the results to inform future directions. Research has opened up many new opportunities for local government, it helps motivate staff to explore solutions to recalcitrant problems, and has expanded and enhanced the quality and quantity of the knowledge base informing decision making. Overall, this contributes to more sustainable and transparent actions that contribute to the overall quality of our environments, communities and lifestyles.

\section{References}

Akama, Y., Chaplin, S., Phillips, R. \& Toh, K. 2012, 'Design-led strategies for bushfire preparedness', paper presented to the Earth: Fire And Rain, Australian \& New Zealand Disaster and Emergency Management Conference, Brisbane, 16-18 April.

Australian Bureau of Statistics (ABS) 2012, Regional Population Growth, Australia, 2010-11, cat. no. 3218.0, ABS, Canberra, viewed 29 April 2013, <http://www.abs.gov.au/AUSSTATS/abs@.nsf/allprimarymainfeatures/81F229EB4F 954422CA257A4B00147807?opendocument>.

Australian Public Service Commission (APSC) 2007, Tackling Wicked Problems - A Public Policy Perspective, APSC, Canberra.

Bureau of Meteorology 2013, 'Australian climate variability \& change - Trend maps', viewed 16 October 2013, <http://www.bom.gov.au/cgi-bin/climate/change/trend maps.cgi>.

Chen, K. 2005, 'Counting bushfire-prone addresses in the Greater Sydney region', paper presented to the Symposium on Planning for Natural Hazards - How Can We Mitigate the Impacts?, Wollongong, 2-5 February.

Commonwealth Auditor-General 2009, Innovation in the Public Sector: Enabling Better Performance, Driving New Directions - Better Practice Guide, Australian National Audit Office, Canberra.

Commonwealth Scientific and Industrial Research Organisation (CSIRO) 2007, Climate Change in the Sydney Metropolitan Catchments, NSW Government, Sydney.

Cottrell, A., Bushnell, S., Spillman, M., Newton, J., Lowe, D. \& Balcombe, L. 2008, 'Community perceptions of bushfire risk', in J. Handmer \& K. Haynes (eds), Community Bushfire Safety, CSIRO Publishing, Collingwood, Victoria, pp. 11-20. 
Crichton, K. 2010, Broader OHS accountability - the impact of rapid urbanisation, Workplace OHS, viewed 30 April 2013, <http://www.workplaceohs.com.au/whs-ohslegislation/model-act-and-regulation/broader-ohs-accountability-the-impact-of-rapidurbanisation>.

Dale, C. 2008, 'The Role of Local Government for a Contemporary Victorian Community', $\mathrm{PhD}$ thesis, Graduate School of Business, Victoria University, Melbourne.

Demographic profile 2011, Profile.ID, viewed 17 May 2013, <http://profile.id.com.au/ ku-ring-gai/population-estimate>.

Department of Planning [NSW] (DoP) 2007, Draft North Subregional Strategy, DoP, Sydney, viewed 17 May 2013, <http://www.planning.nsw.gov.au/StrategicPlanning/ Subregions/NorthSubregion/tabid/479/language/en-US/Default.aspx>.

Erikson, C. \& Prior, T. 2011, 'The art of learning: wildfire, amenity migration and local environmental knowledge', International Journal of Wildland Fire, vol. 20, pp. 61224.

Fernandes, P.M. \& Botelho, H.S. 2003. 'A review of prescribed burning effectiveness in fire hazard reduction', International Journal of Wildland Fire, vol. 12, pp. 117-28.

Field, C.B., Barros, V., Stocker, T.F., Qin, D., Dokken, D.J., Ebi, K.L., Mastrandrea, M.D., Mach, K.J., Plattner, G.-K., Allen, S.K., Tignor, M. \& Midgley, P.M. (eds) 2012, Managing the Risks of Extreme Events and Disasters to Adverse Climate Change Adaptation, Special Report of the Intergovernmental Panel on Climate Change (IPCC), Cambridge University Press, Cambridge, UK.

Hornsby-Ku-ring-gai Bush Fire Management Committee (HKBFMC) 2010, Hornsby Ku-ring-gai Bush Fire Risk Management Plan, HKBFMC, <http://www.hkbf mc.org.au/files/BFRMP_ForWebsite_20111031.pdf>.

Kelly, A.H. 2011, 'The Three Phases of Local Government State of Environment Reports in NSW Australia: Complexity, Intricacy and Creativity', Journal of Economic and Social Policy, vol. 14, pp. 1-19.

Ku-ring-gai Council 2004, Riparian Policy, Ku-ring-gai Council, viewed 16 October 2013, <http://www.kmc.nsw.gov.au/files/4ca31b45-802f-4c3c-b35c-a14f0107ab0c/ Riparian_Policy_adopted14122004.pdf>.

Ku-ring-gai Council 2011, Climate Change Adaptation Strategy, Ku-ring-gai Council, viewed 16 October 2013, <http://www.kmc.nsw.gov.au/files/e22b4e9b-75c0-4238816b-a15000e11836/

Climate_Change_Adaptation_Strategy.pdf >

Ku-ring-gai Council 2012a, Climate Wise Communities Pilot Project Report, Ku-ring-gai Council, Gordon, NSW. 
Ku-ring-gai Council, 2012b, Managing Bushfire Risk Now and into the Future: Ku-ringgai Principal LEP Background Study, Ku-ring-gai Council, viewed 16 October 2013, $<$ http://www.kmc.nsw.gov.au/files/5cb52736-6c3a-4a2f-b3cc-a18800fcef13/KLE P2013_exhibMar_suppdocs_managing_bushfire_risk.pdf $>$.

Martin, J. n.d. Innovative Strategies in Australian Local Government, Occasional Paper no. 4, Australian Housing and Urban Research Institute, viewed 1 May 2013, $<$ http://www.ahuri.edu.au/downloads/publications/Occasional_Paper_4.pdf>.

Northern Sydney Regional Organisation of Councils (NSROC) 2010-11, State of the Environment 2010-2011, NSROC, Lane Cove, NSW.

Pillora, S. \& McKinlay, P. 2011, Local Government and Community Governance: A Literature Review, Australian Centre of Excellence for Local Government, University of Technology, Sydney.

Raymond, C.M., Fazey, I., Reed, M.S., Stringer, L.C., Robinson, G.M. \& Evely, A.C. 2010, 'Integrating local and scientific knowledge for environmental management', Journal of Environmental Management, vol. 91, pp. 1766-77.

Rural Fires Act 1997 (NSW).

Taplin, R., Henderson-Sellers, A., Trueck, S., Mathew, S., Weng, H., Street, M., Bradford, W., Scott, J., Davies, P. \& Hayward, L. 2010, Economic Evaluation of Climate Change Adaptation Strategies for Local Government: Ku-ring-gai Council Case Study, Ku-ring-gai Council, Gordon, NSW. 